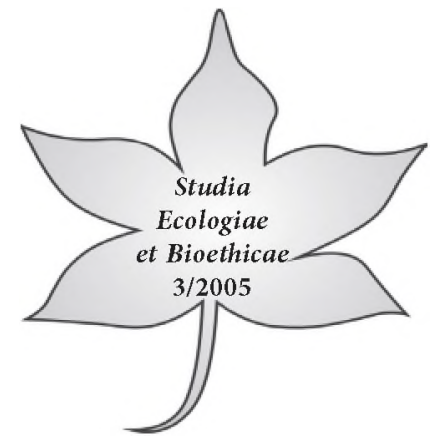

\title{
Wydarzenia i ludzie początków prawnej ochrony przyrody w Polsce
}

\section{Wstęp}

Człowiek już w zamierzchłej przeszłości podejmowal próby otaczania czcią i doraźną pomocą wybranych elementów przyrody zarówno nieożywionej jak i ożywionej. Pierwsze inicjatywy ochrony przyrody, były powodowane motywami religijnej czci oddawanej świętym drzewom czy skałom (pierwowzory pomników przyrody) czy świętym gajom (pierwowzory rezerwatów). Dzięki takim motywom, również i w Polsce zachowano wiele zabytków przyrody. Przykładem może być wielki głaz narzutowy w Budziejewku, z którego jak głosi legenda głosił kazania św. Wojciech. Głaz ten znany jako „Kamień św. Wojciecha”, objęty jest ochroną jako pomnik przyrody. Ryty mistyczne, religijne i kulturowe, to pierwsze motywy skłaniające ludzi do poszanowania i ochrony przynajmniej wybranych elementów przyrody. Z czasem do tych sakralnych motywów doszły przesłanki natury gospodarczej, a stopniowo także społecznej i kulturowej.

Profesor Władysław Szafer w zredagowanej przez siebie pracy na temat historii ochrony przyrody, pisal: Utarło sie przekonanie, ze idea ochrony przyrody jest wytworem kultury końca XIX i początku XX wieku. Zdanie to jest o tyle sluszne, ze istotnie dopiero w tym czasie stala się ochrona przyrody jednym z twórczych czynników wspólczesnej kultury narodów i państw całego nieomal swiata. Niesłuszne natomiast jest takie zapatrywanie, gdy chodzi o jej poczatki, gdyz te siegaja historycznie daleko w przeszłość. Każdy kraj ma na tym polu własnq kartę historyczna, często może jeszcze nie znaną, a raczej zapomnianq, która nieraz dopiero przez żmudne badania archiwalne zostanie kiedyś odkryta i należycie zużytkowana ${ }^{1}$. Również i Polska ma swoją wspaniałą kartę ochrony przyrody, sięgającą swymi korzeniami bardzo daleko w historię naszej państwowości. W artykule tym jednak nie będę sięgał do zamierzchłej przeszłości. Skupię się jedynie na wybranych wydarzeniach i wybitnych osobowościach, końca XIX wieku i lat międzywojennych wieku XX. Wtedy to właśnie

1 W. Szafer, Z dziejów ochrony przyrody, w: Skarby przyrody i ich ochrona, pod red. W. Szafer, Warszawa 1932, s. 16. 
stawiano pierwsze kroki w kierunku systemowej, prawno-instytucjonalnej ochrony przyrody. Najpierw zostaną przedstawione działania wpisujące się w historię rozwoju idei ochrony przyrody w Polsce, a w ostatnim punkcie zostaną przedstawione sylwetki wybitnych przyrodników i propagatorów ochrony przyrody, których nazwiska pojawiły się we wcześniejszym tekście.

\section{Pierwsze próby}

Początków prawnej ochrony przyrody w Polsce należy szukać w drugiej połowie XIX wieku. W epoce tworzenia się państw narodowych ochronie przyrody bardzo dobrze służyły motywy narodowe i nacjonalistyczne. Poprzedziły je dominujące wówczas na terenie naszego kraju prądy kulturowe z końca okresu oświecenia, głoszące „powrót do natury” oraz era romantyzmu, która skierowała ponownie uwagę na piękno przyrody. Rozwinął się kult swojskości. Pod wpływem tych motywów, w Polsce pod rozbiorami ukształtował się sposób widzenia zadań ochrony przyrody w kategoriach sprawy narodowej. Zaowocował on pięknymi efektami w dobie dziewiętnastowiecznej industrializacji, w postaci ochrony estetycznych i wyjątkowych walorów przyrody.

W drugiej połowie XIX wieku doszły do głosu konserwatorskie formy ochrony przyrody. $\mathrm{Z}$ jednej strony były one reakcją na szybki rozwój przemysłu. Z drugiej - na rozwój nauk przyrodniczych, bez których nie do pomyślenia jest industrializacja, bogactwo i rozwój nowoczesnych państw. Można stwierdzić, że idea nowoczesnej ochrony przyrody rodzi się z chwilą zbiegu uczuciowego stosunku do przyrody z pierwszą rewolucją techniczną z połowy XIX wieku.

Rozwój przemysłu doprowadził do wyraźnego zachwiania równowagi przyrodniczej w wielu stronach naszego globu. Także i obszar Polski, znajdującej się pod zaborami, nie był odosobniony w tym względzie. Zagrożenia stawały się coraz bardziej widoczne i uciążliwsze dla życia i zdrowia ludzi. Niszczenie i degradacja środowiska przyrodniczego, najwyraźniej była widoczna na terenach unikatowych o szczególnym pięknie i osobliwości przyrodniczej. Na początku naszego wieku Marian Raciborski, zwracając wagę na czysto utylitarny stosunek człowicka do przyrody, pisał: $W$ zastosowaniu do zabytków przyrody, gruby utylitaryzm tępił je w imię kultury i przemysłu, czasem jedynie skutkiem bezmyślności graniczacej z wandalizmem. Na szerokich terenach Europy wyniszczyl je doszczętnie, zmienił dawny krajobraz, dawna szatę roślinną $i$ zwierzeca. Teraz dopiero, znamienny to szczegól dla umysłowości naszego pokolenia, w wielu punktach kuli ziemskiej prawie jednocześnie zrozumiano strate i rozpoczęto czynności w celu zachowania resztek ${ }^{2}$. Zniszczenie wyjątkowych osobliwości przyrodniczych przez rozwijający się przemysł, były pierwszym i najbardziej widocznymi zjawiskiem motywującym do zatroskania się o naturalne środowisko.

M. Raciborski, Zabytki przyrody, „Ateneum Polskie”, t. I, Lwów 1908, s. 38. 
Innym elementem inspirującym był rozwój nauk przyrodniczych. Wyniki badań polskich przyrodników, botaników, zoologów i geologów z Uniwersytetów Wileńskiego i Warszawskiego, stworzyły niezbędne podstawy naukowe dla ruchu ochrony przyrody. Natomiast trzecim wielkiej wagi czynnikiem inspirującym ochronę naturalnego środowiska, była panująca w tamtym czasie na ziemiach polskich ideologia romantyzmu. Już Jan J. Rousseau wystąpił z hasłem „powrotu do natury”, a romantyzm w literaturze, poezji sztuce, itp., nadał stosunkowi człowieka do przyrody zabarwienie sentymentalne. Dodatkowym atutem romantyzmu na ziemiach polskich znajdujących się w niewoli, był patriotyzm objawiający się umiłowaniem tej ziemi i wszelkich form przyrodniczych na niej się znajdujących ${ }^{3}$. Z tych trzech źródeł wywodzi się idea nowoczesnej ochrony przyrody, przekraczająca użytkowość przyrody i sięgająca do jej wartości idealnych.

\section{Społeczne i patriotyczne zaangażowanie}

W końcu XIX i na początku XX wieku, ochrona przyrody rozwijała się w ramach różnych stowarzyszeń i organizacji. Na terenie ziem Polskich będących ciągle pod zaborami, do takich organizacji należało: Polska Akademia Umiejętności, Polskie Towarzystwo Tatrzańskie i Towarzystwo Przyrodników im. Kopernika w Galicji, Polskie Towarzystwo Krajoznawcze działające na terenie Królestwa kongresowego, na terenie zaboru pruskiego żwy był ruch ochrony przyrody kierowany przez dyrektora muzeum gdańskiego Hugo Conventza. Były to początki nowego okresu w dziejach ochrony przyrody.

W 1874 r., we Lwowie z inicjatywy kół naukowych powstało Polskie Towarzystwo Przyrodników im. Kopernika, które postawiło sobie za cel badanie przyrody ojczystej oraz propagowanie wiedzy o jej wartości i pięknie ${ }^{4}$. Ważną pracą Towarzystwa, było sporządzenie rejestru obiektów przyrodniczych znajdujących się na terenie krajów wchodzących w skład monarchii austryjackiej, a zasługujących na ochronę. Tym praktycznym działaniem Polskie Towarzystwa Przyrodników im. Kopernika odpowiedziało na polecenie Ministra Oświaty w Wiedniu z dnia 30 listopada 1903 r. w sprawie zebrania wiadomości o obiektach przyrodniczych zasługujących na ochronę. Przesłano wtedy spis kilkudziesięciu najcenniejszych pod względem przyrodniczym zabytków oraz propozycję utworzenia większych rezerwatów w Tatrach, Pieninach, Karpatach Wschodnich i na Podolu. Towarzystwu przewodniczył wówczas profesor Marian Raciborski, utrzymujący bliskie kontakty ze wspomnianym wcześniej Hugo Conventzem 5 .

Por. W. Radecki, Zarys dziejów prawnej ochrony przyrody i środowiska w Polsce, Kraków 1990, s. 36-38.

4 Por. tamże, s. 88

5 Por. A. Leńkowa, Aby świat nie stal się pustynia. Karty z historii ochrony przyrody, cz. II, Krajowa Agencja Wydawnicza, Warszawa 1981, s. 16-17. 
Hugo Conventza (1855-1922) można uznać za czołowego działacz ochrony przyrody na Prusach Zachodnich. Z wykształcenia był botanikiem badającym rzadkie rośliny. Zapoczątkował inwentaryzację zabytków natury, której wyniki ogłosił w książce pt. „Forstbotanisches Merkbuch. Nachweis der beachtenswerthen und zu schützenden urwüsigen Sträucher, Bäume und Bestände im Königreichn Preusse. I. Provinz Westpreussen" (Pamiętnik drzew leśnych. Wykaz godnych uwagi i ochrony rodzimych krzewów, drzew i drzewostanów w Królestwie Pruskim I (tom). Prowincja Prus Zachodnich - wydana w 1900 r. Był to wzór dla wielu późniejszych opracowań tego typu na ziemiach niemieckich. Conventz interesował się także losem zwierząt we własnym kraju i za granicą; pisał m. in. o potrzebie ochrony bobra, zółwia, żubra, wilka. Spis jego publikacji obejmuje 261 pozycje, z czego niektóre zostały przetłumaczone na inne języki. Dzięki jego staraniom w Prusach zachodnich i w Poznańskim zabroniono wycinania w lasach państwowych cisa i breki a stare drzewa otoczono opieką. Wydano przy jego współpracy okólniki dotyczące ochrony innych zabytków przyrody a także zadrzewień śródlądowych i nadrzecznych, krajobrazu oraz spraw nauczania ochrony przyrody w szkołach i popularyzowania tej idei pośród starszego społeczeństwa. ${ }^{6}$

W 1903 r. zaistniało Galicyjskie Towarzystwo Tatrzańskie z siedzibą w Nowym Targu. W ramach Towarzystwa Tatrzańskiego, w roku 1912 powstała Sekcja Ochrony Tatr. Była to już organizacja o charakterze wybitnie ochronnym ${ }^{7}$. Inicjatywy chronienia przyrody na terenie zaboru austriackiego, pochodziły od takich wybitnych ludzi tamtych terenów, jak Ludwik Zajszner, Maksymilian Siły -Nowicki i Eugeniusz Jonata, a związane byly głównie z ochroną Tatr.

Ochroną przyrody zajmowano się także w zaborze rosyjskim. W $1906 \mathrm{r}$. Warszawski Urząd Gubernialny zatwierdził status Polskiego Towarzystwa Krajoznawczego. Towarzystwo miało opiekować się osobliwościami przyrodniczymi. W tym celu podjęto inicjatywę inwentaryzacji osobliwych obiektów przyrodniczych ${ }^{9}$. Innym celem Polskiego Towarzystwa Krajoznawczego, było gromadzenie wiadomości krajoznawczych, zbieranie zbiorów naukowych, organizowanie wycieczek po kraju, tworzenie oddziałów prowincjonalnych, urządzanie wystaw krajowych, roztaczanie opieki nad pamiątkami historycznymi i osobliwościami przyrody ${ }^{10}$. W $1908 \mathrm{r}$. w ramach

Za: tamże, s. 14-15.

7 Za: W. Radecki, Polskie Towarzystwo Tatrzańskie i Polskie Towarzystwo Krajoznawcze, "Aura” 1989 nr 9, s 29.

8 K. Kasprzak, J. Skoczylas, Rozwój ochrony przyrody nieożywionej i ożywionej. Historia i wspótczesność, Fundacja WART, Poznań 1993, s. 10.

9 Por. A. Leńkowa, Ochrona przyrody w Polsce, w: Czlowiek przeciwko sobie?, prac. zbior pod red. A. Leńkowa, Instytut Wydawniczy PAX, Warszawa 1977, s. 92.

10 Z. Kulczycki, Zarys historii turystyki w Polsce, Zakład Wydawniczo-Propagandowy PTTK, Warszawa 1977, s. 82-83. 
Towarzystwa Krajoznawczego, powstała Komisja Ochrony Osobliwości Przyrody, która zajęła się gromadzeniem wszelkich wiadomości na temat zabytków i osobliwości przyrody polskiej, a także ochroną i zabezpieczaniem tych cennych przyrodniczo elementów natury. Towarzystwo zajmowało się także prowadzeniem badań naukowych nad warunkami powstawania osobliwości i zabytków oraz nad warunkami życia rzadkich lub wymierających roślin i zwierząt ${ }^{11}$.

Także na terenie zaboru pruskiego, żywy był ruch ochrony przyrody kierowany m.in. przez dyrektora muzeum gdańskiego, wspomnianego wcześniej Hugo Convetza. Działalność tego ruchu polegała na inwentaryzacji i ewidencji pomników przyrody na Pojezierzu Gdańskim. Twórcą pojęcia „pomnik przyrody” był Aleksander Humboldt (1769-1859), niemiecki uczony, przyrodnik i geograf a także żywy entuzjasta i propagator ochrony przyrody. Utrzymywał on żywe kontakty z polskimi środowiskami naukowymi. Otrzymał nawet godność członka honorowego Towarzystwa Przyjaciół Nauki w Warszawie ${ }^{12}$. Tak więc ziemie zaboru pruskiego i żyjący na nich ludzie, wpisują się również w karty historii konserwatorskiej ochrony przyrody ${ }^{13}$. Te działania ochronne we wszystkich zaborach podejmowane były z przyczyn naukowych, historycznych lub patriotycznych. Realizacja ich dokonywała się głównie na drodze społecznego i obywatelskiego zaangażowania.

\section{Działania na rzecz ochrony przyrody po odzyskaniu niepodległości}

Po odzyskaniu niepodległości w roku 1918, przystąpiono niezwłocznie do tworzenia zrębów strukturalnych administracji państwowej. W strukturach administracyjnych nie utworzono specjalnej jednostki lecz włączono kwestię ochrony środowiska przyrodniczego w poszczególne resorty i instytucje prawno-polityczne. Pierwszy akt prawny dotyczący działań zmierzających do ratowania przyrody, został wydany jeszcze przez Radę Regencyjną dnia 31 października 1918 r. Był to dekret dotyczący opieki nad zabytkami sztuki i kultury. W dekrecie tym ustalono, że za zabytki podlegające ochronie można uznać również ogrody ozdobne, aleje cmentarne i przydrożne, drzewa sędziwe i okazałe itp. ${ }^{14}$ Przez cały okres międzywojenny na podstawie tego dekretu (a późnej na podstawie rozporządzenia Prezydenta Rzeczypospolitej z 6 marca 1928 r. o opiece nad zabytkami) można było obejmować ochroną cenne obiekty przyrodnicze.

11 W. Radecki, Zarys dziejów..., dz. cyt., s. 51.

12 Za: A. Leńkowa, Ochrona przyrody w Polsce, w: Czlowiek przeciwko sobie?, dz. cyt., s. 86.

13 Por. J.J. Nowak, Prawo i organizacja ochrony przyrody w Polsce, Wydawnictwo Prawnicze, Warszawa 1967, s. 22.

14 Za: W. Radecki, Tymczasowa Państwowa Komicja Ochrony Przyrody, „Aura” 1989, nr 11/12, s. 16. 
W 1919 r. została utworzona pierwsza państwowa organizacja ochrony przyrody pod nazwą: Tymczasowa Komisja Państwowa Ochrony Przyrody. Był to organ doradczy i opiniotwórczy, działający przy Ministrze Wyznań Religijnych i Oświecenia Publicznego, który w roku 1925 został przekształcony w Państwową Radę Ochrony Przyrody ${ }^{15}$. Państwowa Rada Ochrony Przyrody podjęła pracę nad opracowaniem specjalnej ustawy dotyczącej ochrony przyrody. Rezultatem tych wysiłków była pierwsza polska ustawa o ochronie przyrody, z dnia 10 marca 1934 r. ${ }^{16}$. Jak na owe czasy była to bardzo postępowa ustawa, która nie wyczerpywała się na samym tylko zabytkoznawstwie i konserwatorstwie, ale swoimi przepisami zmierzała do usunięcia dysharmonii, jaką w życiu przyrody i człowieka wprowadziła cywilizacja techniczna. W świetle tej ustawy z 1934 r., ochrona przyrody w naszym kraju traci swój dotychczasowy bierny charakter i zaczyna nabierać aktywności zajmując się np. ochroną biocenotyczną poszczególnych zespołów (rezerwaty) ${ }^{17}$. Chociaż ustawa była postępowa, nie spełniła jednak całkowicie swego zadania, ponieważ władze zwlekały z wydawaniem do niej rozporządzeń wykonawczych.

Warto też wspomnieć o powstaniu w Polsce stowarzyszenia pod nazwą Liga Ochrony Przyrody, które istnieje do dnia dzisiejszego ${ }^{18}$. Inicjatorem utworzenia w Polsce Ligi do spraw ochrony przyrody był wybitny uczony, profesor Władysław Szafer, pionier ruchu ochrony przyrody w naszym kraju. Był on związany od 1919 r. najpierw z Państwową Komisją Ochrony Przyrody, funkcjonującą przy Ministerstwie Wyznań Religijnych i Oświecenia Publicznego, a po jej przekształceniu w roku 1926 w Państwową Radę Ochrony Przyrody (PROP) był jej przewodniczącym i długoletnim członkiem. W 1923 r. przebywając w Szwajcarii, Szafer poznał tamtejszą Ligę Ochrony Przyrody i po powrocie do kraju podjął kroki w celu utworzenia podobnej organizacji w Polsce. Konkretny projekt organizacji Ligi, Profesor przedłożył w grudniu 1926 r. na 31 posiedzeniu wydziału PROP.

Liga miała być związkiem towarzystw rozsianych po całym kraju, zajmujących się ochroną przyrody lub pragnących popierać tą akcję. Gdy projekt stworzenia Ligi zyskał aprobatę ściślejszego grona działaczy ochrony przyrody, przedstawiono go na forum VII Zjazdu PROP w Warszawie, w styczniu 1927 r. ${ }^{19}$ Rok później, na VIII

15 Por. L. Jastrzębski, Ochrona środowiska w PRL. Zagadnienia administracyjne, PWN, Warszawa 1983 , s. 10.

16 Tekst tej ustawy został ogłoszony w: Dz. U. Nr 31, poz. 274.

17 Por. A. Leńkowa, Ochrona przyrody w Polsce, w: Czlowiek przeciwko sobie?, dz. cyt., s. 97-98.

18 Por. L. Jastrzębski, Ochrona środowiska w PRL, dz. cyt., s. 11.

19 Powzięto wówczas decyzje o utworzeniu Ligi i wybrano Komitet Organizacyjny w składzie: Jan Gwalbert Pawlikowski, Bolesław Hryniewiecki, Mieczysław Limanowski, Władysław Szafer i Walery Goetel. Przewodniczącym komitetu został Aleksander Janowski z Warszawy. Por. A. Leńkowa, Dzieje Ligi Ochrony Przyrody w Polsce, LOP Zakład Zadrzewień i Zieleni, Warszawa 1968 , s. 15. 
Zjeździe PROP odbywającym się także w Warszawie, powołano do życia Polską Ligę Ochrony Przyrody. Istniały dwie możliwości nazwy tej organizacji:

1) Liga Ochrony Oblicza Ziemi Polskiej - o szerszych zadaniach,

2) Liga Ochrony Przyrody - o węższym zakresie działania, ku której skłaniał się Władysław Szafer. Ostatecznie wybrano nazwę Liga Ochrony Przyrody, która funkcjonuje do dnia dzisiejszego. Szczegółową historię powstania i rozwoju Ligi Ochrony Przyrody opisuje w książce Dzieje Ligi Ochrony Przyrody w Polsce Antonina Leńkowa. ${ }^{20}$

Głównym celem Ligi Ochrony Przyrody było zachowanie oblicza ziemi ojczystej w jej pierwotnym lub historycznie ukształtowanym stanie. Pierwszą inicjatywą podjętą w tym celu przez Ligę, było ratowanie groty kryształowej w Wieliczce ${ }^{21}$. Liga Ochrony Przyrody, kierowana w pierwszym roku swego istnienia przez profesora Józefa Morozewicza, a później wiele lat przez profesora Bolesława Hryniewieckiego, miała także zająć się ratowaniem piękna przyrody tatrzańskiej i resztek stepów znajdujących się w granicach ówczesnej Polski. Borykając się jednak z trudnościami finansowymi, nie wykupiła potrzebnych terenów pod trzy rezerwaty stepowe na wschodzie kraju ${ }^{22}$. Do innych zadań Ligi należało obok ochrony zabytkowych, osobliwych i przyrodniczo wartościowych obiektów, krzewienie wiedzy i edukowanie szczególnie młodego pokolenie w zakresie przyrody i przyrodoznawstwa. W tym także celu w roku 1933, włączono do programów szkolnych naukę o ochronie przyrody.

\section{Działalność i praca naukowa wybranych polskich przyrodników}

Idea ochrony przyrody podjęta została w różnych kołach naukowych, działających głównie przy Uniwersytetach. W 1865 r. w ramach Towarzystwa Naukowego Krakowskiego powstała Komisja Fizjograficzna, której to działacze zapoczątkowali akcję ratowania kozic i świstaków. Losem tych zwierząt zajął się profesor Ludwik Zejszner, biolog, zoolog i paleontolog żyjący w latach 1805 - 1871. Był on inspektorem górnictwa Rzeczypospolitej Krakowskiej, a w 1857 i 1858 roku wykładowcą mineralogii w Akademii Medyczno-Chirurgicznej w Warszawie. Zajmował się w swojej pracy naukowej florą ziem polskich. Działał na rzecz ochrony zwierząt i ptaków dzikożyjących. Badał paleozoologię ziem polskich i opracował mapę geognostyczną (geologiczną) Królestwa Polskiego. Prowadził dużo badań w zakresie geologii Karpat. Wyniki swoich badań publikował w prowadzonej przez siebie monografii, która ukazywała się jako dodatek do poszczególnych tomów Biblioteki Warszawskiej. Na marginesie swojej działalności naukowej, zajmował

\footnotetext{
20 Zob.: tamże.

21 Por. A. Leńkowa, Początek działalności Ligi Ochrony Przyrody, „Aura” 1988 nr 4, s. 3.

22 Por. A. Leńkowa, Aby świat nie stał się pustynia, dz. cyt., s. 69-70.
} 
się także badaniami gleby. Z tych powodów, można go uznać za pioniera ruchu ochrony przyrody na ziemiach polskich ${ }^{23}$. Prowadząc badania geologiczne w Tatrach, zwrócił uwagę, że z każdym rokiem zmniejsza się liczba „zwierząt halskich”. Był to jego główny przyczynek, do późniejszej prawnej ochrony flory i fauny Tatr. Dalsze badania w tym zakresie kontynuowali dwaj Profesorowie Maksymilian SiłaNowicki (1826-1890) ${ }^{24}$ i Eugeniusz Janota ${ }^{25}$ oraz ich naśladowcy.

Maksymilian Siła-Nowicki (1826-1890) - od 1863 r. prowadził wykłady z zoologii na Uniwersytecie Jagielońskim. W latach 1866-1876 przewodniczył sekcji zoologicznej. Był współzałożycielem Towarzystwa Tatrzańskiego i współinicjatorem ustawy o ochronie świstaka i kozic (1868). Pracował w dziedzinie etnomologii stosowanej. Poświęcił się głównie sprawom rybactwa. W 1879 r. założył Krajowe Towarzystwo Rybackie, badał rozmieszczenie ryb w wodach Galicji i prowadził intensywną akcję zarybiania. Był członkiem i organizatorem badań zoologicznych w Komisji Fizjograficznej przy Towarzystwie Krajoznawczym. ${ }^{26}$

Eugeniusz Janota (1823-1878) - germanista, przyrodnik, ksiądz, geograf roślin, krajoznawca i pionier ochrony przyrody w Polsce. Kontynuował prace Wincentego Pola (1807-1872) przeprowadzając analizy dotyczące głównie roślin zielonych. Od $1827 \mathrm{r}$. był profesorem języka i literatury niemieckiej na Uniwersytecie we Lwowie. Założył Galicyjskie Towarzystwo Ochrony Zwierząt i był współzałożycielem Towarzystwa Tatrzańskiego. Później związał się ze środowiskiem Uniwersytetu Jagiellońskiego. Opublikował Pierwszy polski przewodnik w wyprawach na Babiq Górę, do Tatr i Pienin. ${ }^{27}$

To dzięki m.in. pracy i entuzjazmowi tych dwóch ludzi, w październiku 1868 r., Sejm Krajowy Królestwa Galicji i Lodomerii wraz z Wielkim Księstwem Krakowskim, mógł uchwalić dwie ustawy:

1) względem zakazu łapania, wytępiania i sprzedawania zwierząt alpejskich, właściwych Tatrom, świstaka i dzikich kóz;

2) względem zakazu łapania i sprzedawania ptaków śpiewających i owadożernych $^{28}$.

23 Por. K. Kowalska, Zoologia, w: Zarys dziejów nauk przyrodniczych w Polsce, prac. zbior. pod red. K. Maślankiewicz, Wyd. Wiedza Powszechna, Warszawa 1983, s. 352-353; Zejszner Ludwik, w: Nowa Encyklopedia Powszechna PWN, dz. cyt., t. 6, s. 1008.

24 Por. K. Kowalska, Zoologia, w: Zarys dziejow nauk przyrodniczych w Polsce, dz. cyt., s. 362, Nowicki-Siła Maksymilian, w: Nowa Encyklopedia Powszechna PWN, wyd. I, t. 4, Warszawa1996, s. 540.

25 Por. A. Leńkowa, Ochrona przyrody w Polsce, w: Czlowiek przeciwko sobie?, dz. cyt., s. 87.

26 Por. K. Kowalska, Zoologia, w: Zarys dziejow nauk przyrodniczych w Polsce, dz. cyt., s. 362, Nowicki-Siła Maksymilian, w: Nowa Encyklopedia Powszechna PWN, wyd. I, t. 4, Warszawa 1996, s. 540.

27 Por. Z. Kosiek, Botanika, w: Zarys dziejów nauk przyrodniczych w Polsce, dz. cyt., s. 452; Janota Eugeniusz, w: Nowa Encyklopedia Powszechna PWN, wyd. I, t. 3, Warszawa 1995, s. 134.

28 Za: W. Radecki, Ustawy Sejmu Galicyjskiego, „Aura” 1989, nr 7, s. 23. 
Ustawa o ochronie świstaków i kozic została podpisana przez cesarza Franciszka Józefa w dniu 19 lipca 1869 roku na zamku w Lexenburgu i jako ustawa w tym dniu datowana weszła w życie ${ }^{29}$. Z tymi ustawami Sejmu galicyjskiego i z tą datą można wiązać pojęcie „nowoczesnej” ochrony przyrody. Powszechnie przyjmuje się, iż nowoczesna ochrona przyrody narodziła się $\mathrm{w}$ drugiej połowie XIX wieku a może nawet w początkach XX wieku. W swojej pracy z 1927 r. Prawo ochrony przyrody, Jan Gwalbert Pawlikowski przez nowoczesną ochronę przyrody rozumiał, chronienie przyrody dla jej samej bez względu na jej wartości gospodarcze i użytkowe lecz z motywów natury idealnej ${ }^{30}$. To stwierdzenie staje się swoistym podsumowaniem wcześniejszych działań zmierzających do wzrostu kultury i rozbudzenia świadomości ochrony środowiska przyrodniczego, w którym żyje człowiek.

Duży wkład w to dzieło wniósł swoją pracą badawczą i działalnością naukową wspomniany wyżej Jan Gwalbert Pawlikowski (1860-1939) - profesor, ekonomista, prawnik, autor prac budujący zręby nowoczesnej ideologii ochrony przyrody, miłośnik Tatr. Zasłużył się w polskim ruchu ochrony przyrody wypracowaniem dla ówczesnej koncepcji ochrony przyrody filozoficznej podbudowy i wyznaczeniem ścisłych zasad oraz celów ochronnych. Był autorem wielu publikacji związanych z ochroną przyrody Jego prace to np. Kultura a natura ogłoszona po raz pierwszy w 1913 r. w Lamusie i przedrukowana później w 1938 r. w książce pt. O lice ziemi. Inną bardzo obszerną Jego pracą jest zbiór rozpraw pod wspólnym tytułem Podstawowe zagadnienia ochrony przyrody. Zbiór ów zapoczątkowała praca z 1920 r. pt. "O celach $i$ środkach ochrony przyrody”, w dwa lata później wydana była "Społeczna organizacja ochrony przyrody”, zakończyło zaś ten cykl studium „Prawa ochrony Przyrody”. Znacznie później, jako prawnik, Pawlikowski dokonał kodyfikacji prawa ochrony przyrody w Polsce powojennej. Był też kierownikiem Sekcji Ochrony Tatr przy Towarzystwie Tatrzańskim. ${ }^{31}$

Nowoczesną, opartą na naukowych podstawach ochronę przyrody, rozwijał dalej w Polsce Marian Raciborski (1863-1917) - botanik, uczeń m.in. E. Strasburgera w Bon i K. Goebla w Monachium. Od 1900 r. był członkiem Akademii Umiejętności, prowadził prace badawcze na Jawie, później objął Katedrę Botaniki w Akademii Rolniczej w Dublanach. W 1909 r. został profesorem Uniwersytetu im. Jana Kazimierza we Lwowie, gdzie zorganizował Instytut Biologiczno-Botaniczny. Był też autorem pierwszej mapy geobotanicznej Polski.

29 Tekst projektu przytacza w całości: Z. Kawecki, Stulecie nowoczesnej ochrony przyrody w Polsce (1869 - 1968), „Przegląd Zoologiczny” 1968, nr 3, s. 249-251; tekst oficjalny - Dz. U. Kraj. 1869, cz. XI, nr 26.

30 Por. W. Radecki, Narodziny nowoczesnej ochrony przyrody, „Aura” 1989, nr 6, s. 22-23.

31 Za: A. Leńkowa, Aby świat nie stat się pustyniq. Karty z historii ochrony przyrody, cz. II, Krajowa Agencja Wydawnicza, Warszawa 1981, s. 38-39; W. Szafer, Dzieje ochrony przyrody w Polsce $i$ w innych krajach, w: Ochrona przyrodniczego środowiska człowieka, s, 17-18 (artykuł powielany). 
Pisał i publikował z zakresu anatomii i cytologii roślin, biologii ogólnej, fizjologii roślin, systematyki i florystyki, fitogeografii i paleobotaniki ${ }^{32}$. Z jego inicjatywy rozpoczęła się akcja inwentaryzowania zabytków przyrody na terenie całej Polski. On też jako jeden z pierwszych uczonych i wykładowców, z katedry uniwersyteckiej głosił zasady ochrony przyrody ${ }^{33}$. Zasługą tego uczonego było stworzenie teoretyczno-prawnej podbudowy związanej z ochroną przyrody ${ }^{34}$. Można go śmiało zaliczyć do grona pionierów nowoczesnego ruchu ochrony przyrody w Polsce.

Innymi zasłuzonymi dla rozwoju idei ochrony przyrody w Polsce, byli m.in. tak wybitni naukowcy i przyrodnicy jak:

Jan Sztolcman (1854-1928) - ornitolog, podróżnik, eksplorator fauny Peru i Ekwadoru. Obserwował w latach 1874-1882 powstawania odmian w populacjach kolibrów zamieszkujących doliny izolowane wysokimi łańcuchami gór i zakwestionował darwinowską teorię doboru płciowego przeciwstawiając ją własnej teorii równowagi płciowej, w myśl której jaskrawe ubarwienie samców miało powodować częstsze ich padanie ofiarą drapieżników, co wpływało na korzystniejszy stosunek liczbowy płci. Teoria ta swego czasu zyskała uznanie w niektórych koncepcjach ewolucyjnych. Kontynuował prace podjęte przez W. Tomaszewskiego z zakresu badania ptactwa południowoamerykańskiego i syberyjskiego. Od 1887 r. był Dyrektorem Muzeum Branickich, a od 1928 roku wicedyrektorem Państwowego Muzeum Zoologicznego. Od 1924 r. prowadził wykłady z łowiectwa na SGGW. Założył i redagował Lowcę Polskiego. Zajmował się także badaniami z zakresu arachnologii (głównie pająki Peru). Działał przy międzynarodowym Komitecie Ochrony Ptaków i był inicjatorem międzynarodowej ochrony żubra. To z jego inicjatywy powstało Międzynarodowe Towarzystwo Ochrony Zubra. Był autorem obszernego studium Żubr, jego historia, obyczaje i przeszłość (1926). Zaimował się także problematyką łowiecką ${ }^{35}$. Był więc wielkim przyrodnikiem, propagatorem i działaczem na rzecz ruchu ochrony przyrody w Polsce.

Stanisław Kulczyński (1895-1975) - entuzjasta przyrody, rozwinął głównie we Lwowie żywą działalność naukowa i dydaktyczną. Zajmował się systematyką, geografią i socjologią roślin oraz paleobotaniką. Dużą wartość przedstawiały wyniki jego badań nad torfowiskami, stanowiące syntezę długoletnich prac prowadzonych na terenie Polski. Był pracownikiem Instytutu Biologicznego oraz Ogrodu Botanicznego Uniwersytetu Jagiellońskiego w Krakowie ${ }^{36}$. Prowadząc badania naukowe, starał się dogłębnie poznać prawa przyrody i uczyl swoich słuchaczy przestrzegania i szacunku tychże zasad.

32 Por. Z. Kosiek, Botanika w: Zarys dziejów nauk przyrodniczych w Polsce, dz. cyt., s. 441, 442, 444,446, 452-454; J. M. Dołęga, Zarys sozologii systemowej, Wyd. UKSW, Warszawa 2005, s. 14.

33 Por. J. Nowak, Prawo i organizacja ochrony przyrody w Polsce, Wydawnictwo Prawnicze, Warszawa 1967, s. 22.

34 Por. A. Leńkowa, Ochrona przyrody w Polsce, w: Czlowiek przeciwko sobie?, dz. cyt., s. 89.

35 Por. K. Kowalska, Zoologia, w: Zarys dziejów nauk przyrodniczych w Polsce, dz. cyt., s. 355, 361, 366, 394, 395, Sztolcman Jan, w: Nowa Encyklopedia Powszechna PWN, dz. cyt., t. 6, s. 207.

36 Por. Z. Kosiek, Botanika w: Zarys dziejow nauk przyrodniczych w Polsce, dz. cyt., s. 461, 462-464. 
Adam Wodziczko (1887-1948) - wybitny polski botanik, członek Poznańskiego Towarzystwa Przyjaciół Nauki, od 1920 r. profesor anatomii i fizjologii roślin Akademii Rolniczej w Bydgoszczy, a od 1922 r. profesor Uniwersytetu Adama Mickiewicza w Poznaniu. Członek Państwowej Rady Ochrony Przyrody, który zorganizował w 1936 r. pierwsze międzynarodowe Seminarium Biocenotyki i Ochrony Przyrody na Uniwersytecie im. Adama Mickiewicza w Poznaniu. Z jego inicjatywy powołana została pierwsza w Polsce katedra Ochrony Przyrody na Uniwersytecie im. Mikołaja Kopernika w Toruniu. Stworzył teoretyczne podstawy ochrony przyrody i zajmował się zagadnieniem ochrony krajobrazu. Jest autorem ponad 200 rozpraw i artykułów naukowych. Gorąco angażował się w badania i działalności ochrony przyrody na ziemiach polskich. Jest współtwórcą trzech Parków Narodowych (Wielkopolskiego, Wolińskiego i Słowińskiego). ${ }^{37}$

Adam Wodziczko jako pierwszy w swoich pracach zaczął zwracać uwagę na to, że obok ochrony gatunkowej roślin i zwierząt oraz ochrony osobliwych elementów przyrody nieożywionej, należy działalnością ochronną objęć całe środowisko, w którym występują żywe organizmy. Kładł szczególny nacisk na potrzebę zachowania w jak najbardziej naturalnym, niezmienionym stanie siedlisk występowania określonych gatunków. Zwracał on też uwagę na zachowanie w stanie nienaruszonym zwartych obszarów przyrodniczych naszego kraju ${ }^{38}$. Było to pionierskie podejście odbiegające od konserwatorskich form ochrony na rzecz prawidłowego, zgodnego z prawami ekologii kształtowania większych ekosystemów.

Bolesław Hryniewiecki (1875-1963) - ukończył studia na Uniwersytecie Warszawskim ale za działalność społeczno-polityczną został wydalony z uczelni i zesłany w głąb Rosji. Tam kontynuował studia, a później pracował na Uniwersytecie w Dorpacie i Odessie. Jako botanik i chemik prowadzi dalsze badania i otrzymuje stopień doktora botaniki (najwyższy stopień naukowy w Rosji carskiej) i zostaje profesorem zwyczajnym w Katedrze Morfologii i Systematyki Roślin oraz dyrektorem Ogrodu Botanicznego w Odessie. Ulubionym tematem jego pracy byla historia botaniki. Na tym polu położy największe zasługi, kontynuując w twórczy sposób problematykę poruszaną wcześniej jedynie przez Rostafińskiego. Po I wojnie światowej został powołany na stanowisko profesora systematyki i geografii roślin w Uniwersytecie Warszawskim i na Dyrektora Ogrodu Botanicznego w Warszawie. Od 1922 r. członek Polskiej Akademii Umiejętności, a od 1952 r. członek PAN. Jeden z założycieli i długoletni prezes Polskiego Towarzystwa Botanicznego. Przez długie lata był również członkiem i kierownikiem Polskiej Ligi Ochrony Przyrody. ${ }^{39}$

37 Por. Wodziczko, Adam, w: Encyklopedia powszechna PWN, t. 4., Warszawa 1976, s. 680; Wodziczko Adam, w: Nowa Encyklopedia Powszechna PWN, dz. cyt., t. 6, s. 846; W. Szafer, Dzieje ochrony przyrody w Polsce i w innych krajach (?), art. cyt. s. 20-21; J. M. Dołęga, Zarys Sozologii systemowej, dz. cyt. s 28.

38 A. Leńkowa, Ochrona środowiska a ochrona przyrody, w: Czlowiek przeciw sobie?, dz. cyt., s. 18.

39 Por. Z. Radwańska-Paryska, Prof. Bolesław Hryniewiecki-czlowiek i uczony, „Wiadomości Botaniczne", 7(1963), 3-4, s. 173-184; Z. Kosiek, Botanika, w: Zarys dziejow nauk przyrodniczych 
Władysław Szafer (1886-1970) - światowej sławy botanik, niezwykły dydaktyk, popularyzator wiedzy przyrodniczej, długoletni szef Ogrodu Botanicznego Uniwersytetu Jagiellońskiego w Krakowie, współtwórca wielu parków narodowych i rezerwatów i w końcu pomysłodawcy utworzenia Ligi Ochrony Przyrody. Od 1917 r, Władysław Szafer pracowal jako wykładowca na Uniwersytecie Jagielońskim i był jednocześnie dyrektorem Ogrodu Botanicznego w Krakowie oraz członkiem Państwowej Rady Ochrony Przyrody. Po śmierci Mariana Raciborskiego kontynuował redagowanie Flory Polskiej (od 1919 r.), od 1920 r. członek Polskicj Akademii Umiejętności, a od 1952 r. członek Polskiej Akademii Nauk. W okresie okupacji hitlerowskiej był organizatorem i rektorem konspiracyjnego Uniwersytetu Jagiellońskiego. Pod jego kierownictwem wykształciło się wielu wybitnych badaczy i jemu przede wszystkim zawdzięcza Kraków utrzymanie tradycyjnej roli ośrodka nauk botanicznych, zdobytej na przełomie XIX i XX w. Ogłosił ogółem przeszło 600 prac i artykułów, głównie z zakresu systematyki, geografii, socjologii roślin oraz paleobotaniki i biologii kwiatów. Inicjator i redaktor wielu periodyków i czasopism, m. in.: Ochrona Przyrody i Chrońmy Przyrodę Ojczystą ${ }^{40}$. Na polu naukowym i organizacyjnym pracowal przeszło 60 lat. Był wielkim badaczem, inspiratorem i propagatorem ochrony przyrody polskiej.

Władysław Szafer uważał, że dzika i niezniszczona przyroda jest takim samym dobrem kultury jak zabytki budownictwa czy dzieła wielkich artystów. Walczył nie tylko o sprawy wielkie, dotyczące całości ochrony przyrody, ale stawał w obronie rzeczy i spraw, które z niejednego punktu widzenia mogły wydawać się błahe. Mówił walczę w obronie przyrody przeszto 60 lat i obserwuje dziwne zjawisko: im bardziej bronimy przyrode, im więcej powstaje w jej interesie praw, nakazów i zakazów (na papierze) - tym silniejszy jest najgroźniejszy wróg przyrody - ludzka głupota i bezmyślnośc ${ }^{11}$. Upowszechnił w kraju, stworzoną przez Aleksandra Humboldta, ideę ochrony drzew pomnikowych i wieszania na nich kapliczek. W ten sposób ocalało wiele drzew, a sposób tej nieformalnej ochrony, w niektórych rejonach kraju przetrwał do dziś. Po II wojnie światowej profesor Szafer wciąż był pierwszoplanową postacią polskiej ochrony przyrody, ale prócz dotychczasowej konserwatorskiej jej formy, zaczął propagować nowe podejście. Domagał się dopuszczenia przyrodników do planowania rozwoju gospodarczego kraju, a nade wszystko apelował o poszanowanie prawa dotyczącego środowiska. Uważał, że obecność specjalistów z dziedziny ochrony przyrody przy projektowaniu inwestycji pozwoli na ograniczenie ich negatywnego wpływu na przyrodę ${ }^{42}$. Jak wiemy ten po-

w Polsce, dz. cyt., s. 451 i 458; Hryniewiecki Bolesław, w: Encyklopedia Powszechan, PWN, t. 2. Warszawa 1974, s. 237; Hryniewiecki Bolesław, w: Nowa Encyklopedia Powszechna PWN, wyd. I, t. 2, Warszawa 1995, s. 811.

40 Por. Szafer Władysław, w: Encyklopedia powszechna PWN, t. 4, Warszawa 1976, s. 339; Szafer Władysław, w: Nowa Encyklopedia Powszechna PWN, wyd. I, t. 6, Warszawa 1997, s. 158; Z. Kosiek, Botanika w: Zarys dziejów nauk przyrodniczych w Polsce, dz. cyt., s. 452, 460.

${ }^{41}$ Cyt. za: http://niezapominajka.home.pl/index.php?page=czy_wiesz_ze (5.11.2005 r.).

${ }^{42}$ Por. Zarys dziejów nauk przyrodniczych w Polsce, dz. cyt., s. 454-458. 
stulat wciąż jest wysuwany i w dalszym ciągu nie może trafić do głów decydentów. Nie sposób w krótkiej notce opisać całej działalności i wszystkich osiągnięć tego wybitnego przyrodnika, naukowca i ojca polskiej ochrony przyrody.

Walery Goetel (1889-1972) - geolog i twórca wielu nowatorskich pojęć z zakresu ochrony środowiska, propagator i działacz na rzecz ochrony środowiska przyrodniczego Polski i świata. Studiował w Krakowie, a następnie w Wiedniu. W 1913 r. uzyskał stopień doktora z zakresu geologii i paleontologii, a w siedem lat później objął kierownictwo Katedry Geologii Ogólnej w nowoutworzonej Akademii Górniczej w Krakowie (dziś jest to Akademia Górniczo-Hutnicza), gdzie w 1922 r. został profesorem zwyczajnym ${ }^{43}$.

Jego naukowe zainteresowania koncentrowały się głównie na dwóch nurtach: geologii i powiązanych z nią zagadnieniach ochrony środowiska. Stąd zrodził się pomysł poprowadzenia seminarium dla studentów pod nazwą Ochrona przyrody i zabezpieczenie trwałości użytkowania surowców, którym później przez lata kierował na Akademii Górniczo-Hutniczej. Przez kilkadziesiąt lat działał na rzecz ochrony najcenniejszych terenów przyrodniczych. Przyczynił się w tym czasie do powstania wielu obszarów chronionych, w tym Tatrzańskiego i Pienińskiego Parku Narodowego. Uważany jest za jednego z głównych polskich twórców nowoczesnego kierunku w ochronie przyrody, nazywanego sozologią. Jest twórcą powiedzenia co technika zepsuła, to technika musi naprawić. Napisał i opublikował ponad 300 prac naukowych i popularnonaukowych z dziedziny geologii i ochrony przyrody W swojej pracy naukowej i bogatym życiu społecznym pełnił wiele różnych funkcji. M.in. był: Prezesem Zarządu Głównego Towarzystwa Tatrzańskiego (1935-1939), Członkiem Prezydium Asocjacji Słowackich Towarzystw Turystycznych (1931-1939), Członkiem Rzeczywistym PAN, Członkiem Honorowym Towarzystwa Geologicznego w Wiedniu, Członkiem Amerykańskiego Towarzystwa Geograficznego, Członkiem Zagranicznym Węgierskiego Towarzystwa Geologicznego, Przewodniczącym Komitetu: Nauk Geologicznych PAN, Ochrony Wód PAN, Ochrony Przyrody i jej Zasobów PAN, Przewodniczącym Komisji Wodnej i Surowcowej PAN, Przewodniczącym Towarzystwa Polsko-Austryjackiego, Współorganizatorem Akademickiego Związku Sportowego (AZS). Ponadto współtworzył Międzynarodową Unię Ochrony Przyrody i jej Zasobów (IUCN) ${ }^{44}$. Bez wątpienia Walery Goetel, zapisał się w historii jako czołowy przedstawicieli polskiego ruchu ochrony przyrody.

Dzięki wysiłkom, pracy naukowej, dydaktycznej i społecznej tych wybranych wybitnych przedstawicieli polskiego przyrodoznawstwa, idea ochrony przyrody nabierała coraz bardziej wyraźnych kształtów. Coraz powszechniejszy ruch ochrony przyrody w Polsce, przynosił nowe inicjatywy i konkretne efekty, w postaci działań

43 Por. S. Sokołowski, Ze wspomnień o Walerym Goetlu, „Przegląd Geologiczny”, maj 1973, nr 5 , s. $12-14$

44 Por. tamże; także: http://niezapominajka.home.pl/index.php?page=czy_wiesz_ze (5.11.2005 r.). 
prawnych i instytucjonalnych na rzecz ratowania i kształtowania przyrody naszego kraju. Spuścizna tamtych czasów, w pośredni sposób jest obecna we współczesnym systemie prawnej i instytucjonalnej ochrony przyrody naszego kraju.

\title{
Zakończenie
}

Przedstawione powyżej działania nie wyczerpują całości troski o przyrodę ojczystą, w którą angażowali się najwybitniejsze umysły nauki, kultury i polityki polskiej. Od wczesnych lat XX wieku, obok państwowych organizacji ochrony przyrody i inicjatyw naukowych, trwała także działalność ustawodawcza zmierzająca do zabezpieczenia ojczystej przyrody. Jest to zupełnie osobne zagadnienie, które wymaga oddzielnego opracowania. Wszystkie te przedsięwzięcia i zamierzenia, mogą świadczyć o wysokim poczuciu odpowiedzialności za środowisko przyrodnicze, panującej w świadomości Polaków tamtych czasów. Współczesny świat potrzebuje ludzi nie tylko bogatych w wiedzę, ale przede wszystkim wrażliwych na potrzeby innych osób, a także na otaczającą przyrodę. Skoro historia jest najlepszą nauczycielką życia, to może warto w podejmowanych róznego rodzajach procesach edukacyjnych i wysiłkach na rzecz rozwijania świadomości i kultury ekologicznej, sięgając do tej bogatej i jakże pouczającej spuścizny polskich przyrodników oraz inicjatyw podejmowanych kiedyś na rzecz ratowania i kształtowania środowiska przyrodniczego. Ta lekcja historii, może nauczyć poprawnego organizowania, zarządzania i ochrony środowiska.

\section{Events and people of the beginnings of legal environmental protection in Poland}

\begin{abstract}
The actions presented in the article does not exploit all the care about the nature which the most brilliant scientists and politicians were involved in. Since early years of XXth century, exept the national organisations of environmental protection and science initiatives, there has lasted legislative activity which has aimed to protect the nature. This is completely separe issue which demands separe study. All the undertakings and plans might be a sign of a Polish sense of responsibility for environment. Modern world needs people not only rich in knowledge but above all, sensitive for needs of other people and nature that surrounds us. If the history is the best life's teacher, then maybe it is worth to use this experienced and instructive legacy of polish scientists and initiatives, which were taken for rescuing and creating the natural environment. This history lesson might teach us the correct organizing, management and environmental protection.
\end{abstract}

